\title{
Epidemiology of childhood diabetes mellitus in Finland - background of a nationwide study of Type 1 (insulin-dependent) diabetes mellitus
}

\author{
J. Tuomilehto ${ }^{1}$, R.Lounamaa ${ }^{1}$, E. Tuomilehto-Wolf ${ }^{1}$, A. Reunanen ${ }^{2}$, E. Virtala ${ }^{1}$, E. A. Kaprio ${ }^{3}$, H. K. Åkerblom ${ }^{4}$ \\ and the Childhood Diabetes in Finland (DiMe) Study Group* \\ ${ }^{1}$ National Public Health Institute, Department of Epidemiology, ${ }^{2}$ Research Institute for Social Security, Social Insurance Institution, \\ ${ }^{3}$ First Department of Paediatrics, and ${ }^{4}$ Second Department of Paediatrics, The Children's Hospital, \\ University of Helsinki, Helsinki, Finland
}

\begin{abstract}
Summary. A nationwide study of childhood Type 1 (insulindependent) diabetes mellitus was established in 1986 in Finland, the country with the highest incidence of this disease worldwide. The aim of the project called "Childhood Diabetes in Finland" is to evaluate the role of genetic, environmental and immunological factors and particularly the interaction between genetic and environmental factors in the development of Type 1 diabetes. From September 1986 to April 1989, 801 families with a newly-diagnosed child aged 14 years or younger at the time of diagnosis were invited to participate in this study. The vast majority of the families agreed to participate in the comprehensive investigations of the study. HLA genotypes and haplotypes were determined in 757 families $(95 \%)$. Our study also incorporates a prospective family study among non-diabetic siblings aged 319 years, and two case-control studies among the youngonset cases of Type 1 diabetes. During 1987-1989, the overall
\end{abstract}

incidence of Type 1 diabetes was about 35.2 per 100,000 per year. It was higher in boys (38.4) than in girls (32.2). There was no clear geographic variation in incidence among the 12 provinces of Finland. Of the 1,014 cases during these 3 years only six cases were diagnosed before their first birthday. The incidence was high already in the age group 1-4-years old: 33.2 in boys and 29.5 in girls. Of the 801 families $90(11.2 \%)$ were multiple case families, of which 66 had a parent with Type 1 diabetes at the time of diagnosis of the proband. The prevalence of Type 1 diabetes in the parents of these newlydiagnosed diabetic children was higher in fathers $(5.7 \%)$ than in mothers $(2.6 \%)$.

Key words: Type 1 (insulin-dependent) diabetes mellitus, epidemiology, genetic-environmental interaction, incidence, familial occurrence.
The incidence of Type 1 diabetes in Finnish children is higher than in children in other populations [1-5]. The incidence has increased steeply in Finland during the last decades [5-8]. The reasons for the high and rising incidence of childhood diabetes in Finland are not known.

The aetiology of Type 1 diabetes is still rather poorly understood. The major genetic predisposition to Type 1 diabetes is undoubtedly conferred by the HLA-region on chromosome 6 [9]. The question remains open whether a diabetes susceptibility gene (or genes) exists in the HLAregion, or whether structural configurations of specific HLA-haplotypes, which are increased in Type 1 diabetic patients play a role in conferring susceptibility to Type 1 diabetes. HLA haplotypes were used in this study as main markers for susceptibility to Type 1 diabetes. It is also commonly agreed that environmental factors play a role in the initiation of the disease $[10,11]$. Environmental

\footnotetext{
$*$ The Childhood Diabetes in Finland (DiMe) Study Group, see acknowledgements.
}

determinants of Type 1 diabetes have not yet been identified, nor has the potential mechanism of action of proposed factors. The present concept is that in some of the genetically susceptible individuals a triggering factor can affect pancreatic Beta cells which leads to an autoimmune process causing a gradual loss of insulin secretion and the manifestation of diabetes $[12,13]$. Clearly, more information about the interaction between genetic and environmental factors in the development of Type 1 diabetes is essential for the prevention of Type 1 diabetes [14].

Finland is an ideal country to study the aetiology of Type 1 diabetes, because of the high incidence of the disease, Finland's genetically homogeneous population and the well-organized care for diabetic children. In 1986 we started a nationwide study called "Childhood Diabetes in Finland" (abbreviated: DiMe). The aim is to evaluate the role of genetic, environmental and immunological factors and their interactions in the development of Type 1 diabetes in a large cohort of newly-diagnosed diabetic children and their families. The purpose of this paper is to 
Table 1. Recruitment to the DiMe study of newly-diagnosed diabetic children aged 14 years and under during September 1986 to April 1989

\begin{tabular}{llll}
\hline & $\begin{array}{l}\text { Number of } \\
\text { participating } \\
\text { hospitals }\end{array}$ & $\begin{array}{l}\text { Number of } \\
\text { newly-diag- } \\
\text { nosed cases } \\
\text { registered }^{\text {a }}\end{array}$ \\
\hline $\begin{array}{l}\text { September } \\
\text { December }\end{array}$ & $1986-$ & 60 \\
$\begin{array}{l}\text { January } \\
\text { February }\end{array}$ & $1987-$ & 13 & \\
$\begin{array}{l}\text { March } \\
\text { December }\end{array}$ & $1987-$ & 15 & 45 \\
$\begin{array}{l}\text { January } \\
\text { December }\end{array}$ & $1988-$ & 31 & 248 \\
$\begin{array}{l}\text { January } \\
\text { April }\end{array}$ & $1989-$ & 31 & 328 \\
Total & 1989 & 31 & 130 \\
\hline
\end{tabular}

${ }^{a}$ In 801 families, because 10 cases diagnosed in siblings aged 14 years and under, occurred in eight families that already had another case diagnosed during the DiMe study

describe the design and the basic epidemiological findings of the DiMe study.

\section{Subjects and methods}

\section{Target population}

Finland, a relatively sparsely populated country has a homogenous population of 4.9 million of which $93.5 \%$ are Finnish-speaking and $6.3 \%$ Swedish-speaking. There are about 1,300 ethnic Lapps and 50,000 foreigners living in Finland. The majority of the population lives in the southern or southwestern part of the country. Thus, the population density markedly varies between the 12 provinces of Finland. In 1987-1989, the average number of inhabitants aged 14 years and under was 467,000 males and 488,000 females.

In Finland all newly-diagnosed diabetic children are hospitalized for approximately 1-2 weeks. All 33 hospitals in which diabetic children are treated in Finland agreed to participate in the DiMe study (in two hospitals no new cases were diagnosed during the study). In each of the hospitals a paediatrician and a nurse in charge of the care of diabetic children were responsible for and trained in the study procedures and data collection of the DiMe study.

In September 1986, data collection began first with the Departments of Paediatrics of the five University hospitals and eight other hospitals covering different areas and about $75 \%$ of the population of Finland (Table 1). During early 1987 the study was expanded to cover the entire country. Since 1 January 1987, basic epidemiological data and family information have been available nationwide from every newly-diagnosed case of Type 1 diabetes diagnosed in children aged 14 years and under. Detailed information was collected from the consequently registered cases and their families (Table 2). The recruitment of families into the DiMe study was closed by 30 April 1989. The registration of newly-diagnosed cases and the collection of the basic epidemiological data is, however, still continuing nationwide.

\section{Prospective registration of newly-diagnosed cases of Type 1 diabetes}

The aim of this part of the study is to provide a wide range of descriptive epidemiological, genetic, immunological, clinical and environmental risk factor (diet, viral exposures, life events) data in a large
Table 2. Summary of data collection in the DiMe Study

\begin{tabular}{|c|c|c|c|c|}
\hline Data component/Form & $\begin{array}{l}\text { Pro- } \\
\text { band }\end{array}$ & Parents & $\begin{array}{l}\text { Siblings } \\
3-19 \text { years }\end{array}$ & $\begin{array}{l}\text { Siblings } \\
\text { less than } 3 \\
\text { or more } \\
\text { than } \\
19 \text { years }\end{array}$ \\
\hline $\begin{array}{l}\text { Family identification form } \\
\text { - at diagnosis of the proband }\end{array}$ & + & + & + & + \\
\hline $\begin{array}{l}\text { Clinical data } \\
\text { - at diagnosis } \\
\text { - at } 6,12,18 \text { and } 24 \text { months }\end{array}$ & $\begin{array}{l}+ \\
+\end{array}$ & - & - & - \\
\hline $\begin{array}{l}\text { Baseline data on personal } \\
\text { and family history }\end{array}$ & + & + & + & $-\ldots$ \\
\hline $\begin{array}{l}\text { HLA typing } \\
\text { DNA-samples }\end{array}$ & $\begin{array}{l}+ \\
+\end{array}$ & + & $\begin{array}{l}+ \\
+\end{array}$ & $\begin{array}{l}-1+a \\
-\end{array}$ \\
\hline $\begin{array}{l}\text { Serum ICA and IAA } \\
\text { - at diagnosis of the proband } \\
\text { - at } 6,12,18,24,36 \text { and } \\
48 \text { months }\end{array}$ & + & - & $\begin{array}{l}+ \\
+\end{array}$ & - \\
\hline $\begin{array}{l}\text { Other organ and non-organ- } \\
\text { specific autoantibodies } \\
\text { - at diagnosis of the proband } \\
\text { - at } 12,36 \text { and } 48 \text { months }\end{array}$ & $\begin{array}{l}+ \\
+\end{array}$ & - & $\begin{array}{l}+ \\
+\end{array}$ & $\begin{array}{l}- \\
-\end{array}$ \\
\hline $\begin{array}{l}\text { Serum C-peptide } \\
\text { - at diagnosis of the proband } \\
\text { - at } 6,12,18 \text { and } 24 \text { months }\end{array}$ & $\begin{array}{l}+ \\
+\end{array}$ & - & $\begin{array}{l}+ \\
+\end{array}$ & - \\
\hline $\begin{array}{l}\text { Intravenous glucose tolerance } \\
\text { test (in ICA and/or IAA } \\
\text { positives only) } \\
\text { - at } 6,12,18,24,36 \text { and } \\
48 \text { months }\end{array}$ & - & - & + & - \\
\hline $\begin{array}{l}\text { Fasting serum proinsulin } \\
\text { - at diagnosis of the proband } \\
\text { - at } 6,12 \text { and } 24 \text { months }\end{array}$ & + & - & $\begin{array}{l}+ \\
+\end{array}$ & - \\
\hline $\begin{array}{l}\text { Serum viral antibodies } \\
- \text { at diagnosis of the proband } \\
\text { - at } 6,12,18,24,36 \text { and } 48 \\
\text { months }\end{array}$ & + & $\begin{array}{l}- \\
-\end{array}$ & + & - \\
\hline $\begin{array}{l}\text { Serum cow milk antibodies } \\
\text { - at diagnosis of the proband } \\
\text { - at } 6,12,18 \text { and } 24 \text { months }\end{array}$ & $\begin{array}{l}+ \\
+\end{array}$ & - & $\begin{array}{l}+ \\
+\end{array}$ & - \\
\hline $\begin{array}{l}\text { Dietary data } \\
\text { - at the diagnosis of the proband } \\
\text { - at } 12 \text { and } 24 \text { months }\end{array}$ & + & $\begin{array}{l}\text { (mother: } \\
\text { pregnancy) }\end{array}$ & + & - \\
\hline $\begin{array}{l}\text { Life-event data } \\
- \text { at the diagnosis of the proband } \\
\text { - at } 12 \text { and } 24 \text { months }\end{array}$ & + & - & $\begin{array}{l}+ \\
+\end{array}$ & - \\
\hline
\end{tabular}

a Some siblings aged less than 3 years or 19 years and more were HLA typed when important or upon family request ICA, islet cell autoantibodies; IAA, insulin autoantibodies

and unselected patient series. Each of the data components will be described and their data analysed separately in specific reports, but the main advantage of this extensive data set will be the possibility of testing hypotheses of genetic-environmental interaction. Briefly, dietary data consist of mainly qualitative assessment of dietary factors that have been suggested to be associated with an increased risk of Type 1 diabetes, e.g. breast feeding, intake of cow's milk, nitrosamines and coffee, primarily using standardized food frequency questionnaires. One aim was to obtain data on dietary history for the entire lifetime of the probands prior to the diagnosis of diabetes including some possible in utero exposures. Dietary data were obtained through the parents. Viral exposure data consist of data on 
Table 3. The prevalence of diabetes and the proportion of subjects HLA-typed among the family members of newly-diagnosed children with Type 1 (insulin-dependent) diabetes mellitus aged 14 years and under

\begin{tabular}{|c|c|c|c|c|c|c|}
\hline \multirow[t]{2}{*}{ Family members } & \multirow[t]{2}{*}{ Diabetes status } & \multicolumn{2}{|c|}{$\begin{array}{l}\text { Probands and their family } \\
\text { members }\end{array}$} & \multirow{2}{*}{$\begin{array}{l}\text { Alive at the time of } \\
\text { the diagnosis pro- } \\
\text { band }\end{array}$} & \multicolumn{2}{|c|}{$\begin{array}{l}\text { Subjects HLA-typed by March } \\
1991 \text { (of those known and alive) }\end{array}$} \\
\hline & & $n$ & $\%$ & & $\bar{n}$ & $\%$ \\
\hline Fathers $^{a}$ & $\begin{array}{l}\text { Non-diabetic } \\
\text { Type } 1 \text { diabetes } \\
\text { Type } 2 \text { diabetes }\end{array}$ & $\begin{array}{r}737 \\
45 \\
8\end{array}$ & $\begin{array}{r}93.3 \\
5.7 \\
1.0\end{array}$ & $\begin{array}{r}740 \\
43 \\
7\end{array}$ & $\begin{array}{r}640 \\
37 \\
4\end{array}$ & $\begin{array}{l}86.5 \\
86.0 \\
57.1\end{array}$ \\
\hline $\begin{array}{l}\text { Siblings }{ }^{\mathrm{b}} \\
\text { (3-19 years only) }\end{array}$ & $\begin{array}{l}\text { Non-diabetic } \\
\text { Type } 1 \text { diabetes }\end{array}$ & $\begin{array}{r}833 \\
26\end{array}$ & $\begin{array}{r}96.8 \\
3.1\end{array}$ & $\begin{array}{r}819 \\
26\end{array}$ & $\begin{array}{r}720 \\
26\end{array}$ & $\begin{array}{r}88.1 \\
100.0\end{array}$ \\
\hline $\begin{array}{l}\text { Siblings } \\
\text { (all) }\end{array}$ & $\begin{array}{l}\text { Non-diabetic } \\
\text { Type } 1 \text { diabetes }\end{array}$ & $\begin{array}{r}1036 \\
28\end{array}$ & $\begin{array}{r}97.2 \\
2.7\end{array}$ & $\begin{array}{r}1020 \\
28\end{array}$ & $\begin{array}{r}733 \\
28\end{array}$ & $\begin{array}{r}74.1 \\
100.0\end{array}$ \\
\hline
\end{tabular}

a In addition to the deceased fathers no information about the father was available in another 11 families because the father did not live with the family, mainly due to a divorce. ${ }^{\mathrm{b}}$ Of the 232 siblings who were not invited to the DiMe study 135 were less than 3 years of age and 70 over 19 years of age

history of infections and vaccinations, virus antibodies in sera, and virus culture of faeces. History data were collected both by a standard questionnaire and the review of records from child health clinics, which all Finnish children visit at regular intervals. Life-event data were collected using pre-tested standard form and cover the entire lifetime up to the diagnosis of diabetes.

\section{Prospective family study}

The aim of the family study is to determine the familial occurrence of Type 1 diabetes and to assess prospectively the effect of genetic and environmental factors on the risk of the disease in non-diabetic siblings of the probands. Because of potential ethical and logistic problems, only siblings aged more than 3 and less than 19 years were included in the prospective study, as it required clinic visits and blood sampling every 6 months in addition to the questionnaire data (Table 3). The siblings were first investigated at the time of the diagnosis of the proband and were subsequently followed for 2-4 years. Therefore, we were able to monitor the incidence of diabetes in the siblings in relation to various potential determinants of Type 1 diabetes.

The DiMe study is the first population-based family study, in which HLA genotypes and haplotypes of newly-diagnosed diabetic children and their first degree relatives have been determined. The HLA-identical and haploidentical siblings of the probands form a suitable cohort for a prospective study. Non-diabetic siblings who had a positive test result either for islet cell antibodies or insulin autoantibodies were invited every 6 months to an intravenous glucose tolerance test in order to investigate early signs of a disease process.

\section{Case-control studies}

Two separate case-control studies were incorporated in the DiMe study. The first one used age- and sex-matched control children randomly selected from the National Population Register for each proband. Three potential control subjects were chosen - one born on the same day, one born the day before and one the day after the proband. They were contacted by mail at least twice in this order, until a control subject was found. The parents of the control children received the study questionnaires and returned them by mail. Control children $(n=112)$ matched with the early-onset diabetic cases (6 years and under, $n=122$ ) during one year May 1988-April 1989 were interviewed during a home visit, and blood samples were collected for viral and other antibodies and for HLA typing. HLA genotypes were determined in the control children, 109 of their mothers and in 101 fathers.

The other case-control study primarily examines possible inutero exposures. It comprises the probands of the DiMe study who were born after April $1983(n=204)$. Since 1983 the National Public Health Institute has kept frozen serum samples from all Finnish pregnant women taken during the first trimester. Another control will be chosen from the serum bank matching for the date of sample collection and for maternal age. Viral antibodies and possibly some other putative in utero exposures will be determined in these sera.

\section{Data collection procedures}

Immediately after Type 1 diabetes was diagnosed in a child, the diabetes nurse from the local hospital telephoned the DiMe Central Office located at the Department of Epidemiology at the National Public Health Institute in Helsinki, where a serial number for each new family was assigned. During the subsequent days the diabetes nurse filled in the first form (Family Identification Form) comprising a list of all first degree family members, i.e. biological parents and siblings, their life status and the willingness of each family member to participate in the detailed examinations and interviews of the study. The willingness to participate was very high (Table 2), but it was slightly less among fathers ( 8 of 42 Type 1 diabetic fathers who were alive refused) and siblings than among probands and mothers. Of the 14 parents who were deceased prior to the diagnosis of the proband 2 of 11 fathers had Type 1 diabetes and one father had Type 2 (non-insulin-dependent) diabetes.

The diabetes status of each case which was reported on the Family Information Form was checked against the data of the National Central Drug Registry based on the approvals for free-of-charge medication for diabetes at the Social Insurance Institution. Of the 801 cases in the DiMe study, 800 had also been registered in the Central Drug Registry. One proband of the DiMe study died soon after diagnosis from diabetic ketoacidosis. This case was obviously not included in the National Central Drug Registry. Thus, the case-ascertainment of the DiMe study was complete. It also confirmed that insulin treatment in childhood diabetes is always started in hospitals in Finland.

Information on the occurrence of other major diseases in the probands and other family members was obtained by the Family 
Table 4. Number of newly-diagnosed diabetic children aged 14 years and under invited to the DiMe study during September 1986 to April 1989 by age and sex

\begin{tabular}{llrlrlr}
\hline $\begin{array}{l}\text { Age group } \\
\text { (years) }\end{array}$ & \begin{tabular}{l} 
Female \\
\cline { 2 - 7 }
\end{tabular} & $\begin{array}{l}\text { Number } \\
\text { of sub- } \\
\text { jects }\end{array}$ & \multicolumn{2}{l}{ Male } & \multicolumn{3}{l}{$\begin{array}{l}\text { Number } \\
\text { of sub- } \\
\text { jects }\end{array}$} & $\begin{array}{l}\text { Total } \\
\text { jumber } \\
\text { of sub- } \\
\text { jects }\end{array}$ & \\
\hline 0 & 2 & 0.6 & 4 & 0.9 & 6 & 0.7 \\
$1-4$ & 81 & 22.1 & 99 & 22.3 & 180 & 22.2 \\
$5-9$ & 150 & 41.0 & 162 & 36.4 & 312 & 38.5 \\
$10-14$ & 133 & 36.3 & 180 & 40.5 & 313 & 38.6 \\
Total & 366 & 100.0 & 445 & 100.0 & 811 & 100.0 \\
$\%$ & $(46.2)$ & & $(54.8)^{a}$ & & $(100.0)$ & \\
\hline
\end{tabular}

${ }^{a} p<0.01$ between males and females

Table 5. Incidence of Type 1 (insulin-dependent) diabetes mellitus diagnosed in children aged 14 years and under in Finland during the full calendar years 1987 to 1989 by age group and sex

\begin{tabular}{lcrrcc}
\hline Sex & $\begin{array}{l}\text { Age } \\
\text { group }\end{array}$ & \multicolumn{1}{l}{$\begin{array}{l}\text { Popula- } \\
\text { tion }\end{array}$} & $\begin{array}{l}\text { Number } \\
\text { of cases }\end{array}$ & $\begin{array}{l}\text { Yearly inci- } \\
\text { dence per } \\
100,000\end{array}$ & $\begin{array}{l}95 \% \text { con- } \\
\text { fidence in- } \\
\text { terval }\end{array}$ \\
\hline Female & $<1$ & 29,913 & 2 & 2.2 & $0.3-8.1$ \\
& $1-4$ & 123,260 & 109 & 29.5 & $24.2-35.6$ \\
& $5-9$ & 158,287 & 175 & 36.9 & $31.6-42.7$ \\
& $10-14$ & 156,129 & 165 & 35.2 & $30.1-41.0$ \\
& All & 467,589 & 451 & 32.2 & $29.3-35.3$ \\
Male & $<1$ & 31,283 & 4 & 4.3 & $1.2-10.9$ \\
& $1-4$ & 128,542 & 128 & 33.2 & $27.7-39.5$ \\
& $5-9$ & 165,618 & 207 & 41.7 & $36.2-47.7$ \\
& $10-14$ & 163,513 & 224 & 45.7 & $39.9-52.1$ \\
& All & 488,956 & 563 & 38.4 & $35.3-41.7$ \\
All & $<1$ & 61,196 & 6 & 3.3 & $1.2-7.1$ \\
& $1-4$ & 251,802 & 237 & 31.4 & $27.5-35.6$ \\
& $5-9$ & 323,905 & 382 & 39.3 & $35.5-43.5$ \\
& $10-14$ & 319,642 & 389 & 40.6 & $36.6-44.8$ \\
& All & 956,545 & 1014 & 35.3 & $33.2-37.6$ \\
\hline
\end{tabular}

Questionnaire. At the hospitals the medical history of the probands was evaluated as proposed by the National Diabetes Data Group [15], in order to detect and exclude probands in whom diabetes could be secondary due to another disease e.g. Down's syndrome (two cases). The criteria for the diagnosis of Type 1 diabetes in the DiMe study were the same as recommended by the Diabetes Epidemiol ogy Research International group [3-5].

This paper presents data for the DiMe study case recruitment period from September 1986 to April 1989. Because of the potential problems with seasonal variation in onset of clinical symptoms and in defining population denominators we will also present incidence data for three full calendar years 1987 to 1989 for which nationwide epidemiological data have been collected as part of the DiMe study. The population distribution in children of 14 years and under in the 1980 census in Finland in 1-year intervals was used as standard for age standardization.

\section{Statistical analysis}

The $95 \%$ confidence interval for the incidence was computed assuming the Poisson distribution. Differences in proportions were tested with a chi ${ }^{2}$-test.

\section{Results}

From September 1986 through April 1989, 801 families had a case of Type 1 diabetes diagnosed and were thus invited to participate in the DiMe Study. There were 10 additional children in eight families, who also developed Type 1 diabetes during the study period. There was a male predominance, $54.8 \%$ of the cases were boys $(p<0.01)$. Out of the 801 probands (440 boys and 361 girls) 750 children agreed to participate in the full research procedures of the DiMe Study. Only six probands were less than 1 year old at the time of diagnosis (Table 4). The youngest case was diagnosed at 9 months of age.

During the three full calendar years 1987 to 1989 a total of 1,014 new cases of Type 1 diabetes in children aged 14 years and under were diagnosed in Finland. The average annual age-standardized incidence of Type 1 diabetes in children of 14 years and under was $35.3 / 100,000$ (Table 5). It was higher in males, $38.4 / 100,000$ (95\% confidence interval (CI) 35.3-41.7) than in females, $32.2 / 100,000$ (95\% CI29.3-35.3). The male predominance was found in all age groups, but it was most pronounced in the 10-14-year age group. In males the incidence rose with age. It was highest, 45.7 among 10-14 years old, whereas in females the highest age group specific incidence, $36.9 / 100,000$ was found already in the 5-9-year old group.

The variation in incidence among the 12 provinces of Finland was not statistically significant (Fig.1). The overall age-standardized annual incidence remained rather stable during the 3-year period 1987-1989, approximately 35 per 100,000 . In males it increased slightly (yearly rates 36.3 , 36.8 and 40.5 , respectively) whereas in females it decreased (yearly rates $34.0,31.9,29.7$ ). Thus, the male/female ratio of incidence increased from 1.07 in 1987 to 1.36 in 1989.

The prevalence of Type 1 diabetes at the time of diagnosis of the proband was significantly higher $(p<0.001)$ in fathers $(5.7 \%)$ than in mothers $(2.6 \%)$ (Table 3$)$. The number of children in the families, where the mother had Type 1 diabetes $(1.8$ children) was lower $(p<0.05)$ than in the families, where the father had Type 1 diabetes ( 2.3 children). No family where both parents had Type 1 diabetes was registered in the DiMe study. The average number of children in all 801 families of our study was 2.3 . Of all 1064 biological siblings, $28(2.6 \%)$ had Type 1 diabetes at the time of the diagnosis of the proband. Of the 845 siblings aged 3 to 19 years who were invited to the DiMe study $26(3.1 \%)$ had Type 1 diabetes. In 163 families the proband was the only child.

\section{Discussion}

The prospective registration of cases of Type 1 diabetes in the DiMe study confirmed that the incidence of Type 1 diabetes diagnosed under the age of 15 years in Finland is the highest in the world. Earlier epidemiological reports of Type 1 diabetes in Finland have mainly been based on records from the Social Insurance Institution (Central Drug Registry) which reimburses drug costs for certain diseases including diabetes $[1-8,16]$. An earlier comparison between the Central Drug Registry and the hospital 


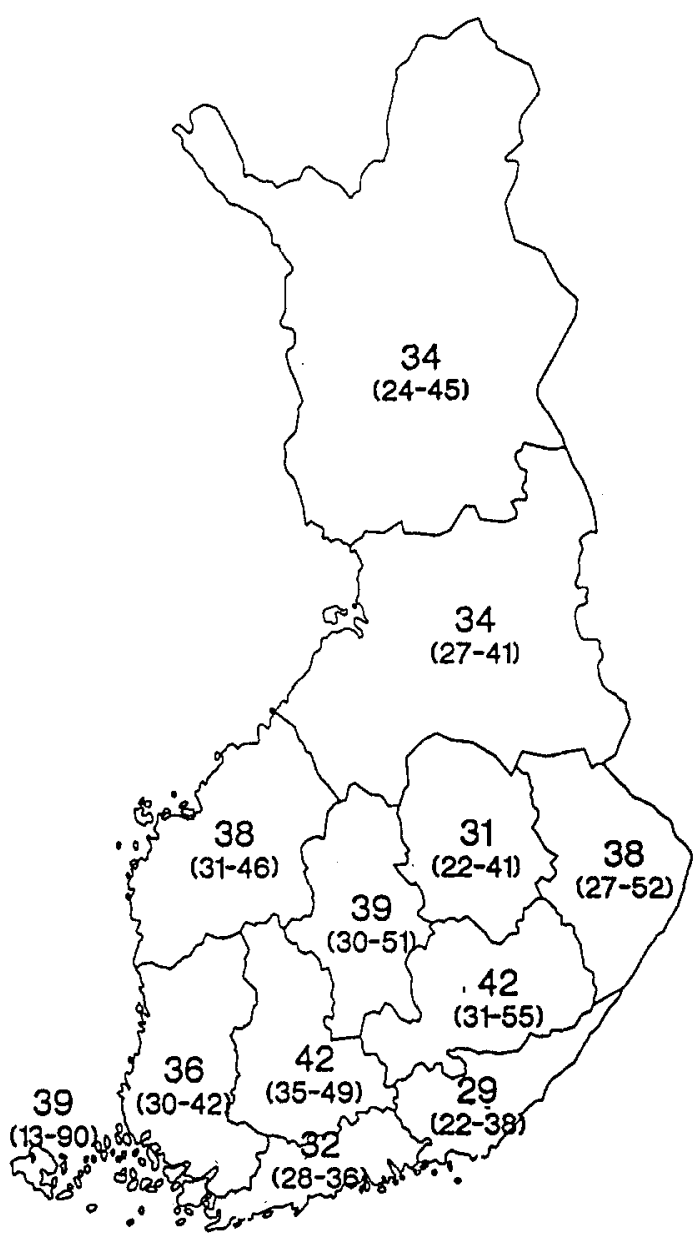

Fig. 1. The incidence of Type 1 (insulin-dependent) diabetes mellitus in 1014 Finnish children aged 14 years and under by province during 1987-1989 according to the province of residence at the time of diagnosis. The average annual incidence for 1987-1989 was 35 per $100,000(95 \%$ confidence interval 33-38). Incidence for boys and girls is combined. $95 \%$ confidence interval is given in parentheses

discharge data collected in Northern Finland showed good agreement between these two sources [16]. During a period of approximately 3 years only one new case of our nationwide prospective diabetes register did not enter the Central Drug Registry, because he died shortly after the first hospital admission. The overall incidence during 1987-1989, 35 per 100,000 per year, was slightly lower than that in 1986 (about 40 per 100,000), the highest ever recorded nationwide annual incidence of diabetes for children of 14 years and under [7]. However, inferences regarding the incidence trend after 1986 cannot yet be conclusive.

A male predominance in the incidence of Type 1 diabetes diagnosed under the age of 15 years was seen. This is in accord with previous Finnish data $[1-8,16]$. The international comparison of the incidence data by the Diabetes Epidemiology Research International Group demonstrated that a male predominance is found in populations with a high incidence, whereas in low incidence populations a slight female predominance is often seen $[4$, 5]. Usually these gender differentials - although consistent do not reach the level of statistical significance, be- cause they have either not been very large or the number of cases has been small. In our present study the $19 \%$ difference in incidence was significant.

Epidemiologically sound study designs combining strong immunogenetic, virological and other methods of basic research are essential for the search of the aetiology of Type 1 diabetes. During the present DiMe study we succeeded in recruiting the majority of all newly-diagnosed Type 1 diabetic Finnish children aged 14 years and under, and their families. The ultimate aim of the DiMe study is to find the reasons for the very high incidence of diabetes in Finland and to provide new data on the aetiology of Type 1 diabetes. The present material of 750 participating families has sufficient power to test various aetiological hypotheses. Moreover, HLA genotypes and haplotypes have been determined in 2,933 family members in 757 DiMe families. To study HLA genetics on a population basis has not been attempted before. Detailed data on shared genetic factors and shared environmental exposures will permit us to estimate their relative effect on the risk of the disease among siblings. Therefore, we will have a solid and large genetic data base for testing different proposed models of the mode of inheritance of Type 1 diabetes (17-20). One of the aims of our study was to find out whether there was a genetic reason for the high incidence of Type 1 diabetes in Finland.

The family study design is essential for detailed genetic analyses and for estimation of the extent to which the high incidence of Type 1 diabetes in Finland is caused by genetic factors. The first results from the HLA genetic data suggested that genetic factors contribute to the high incidence of Type 1 diabetes in Finland [21]. However, given the steep increase in the incidence of childhood diabetes in Finland during the past decades [1, 5-8, 22], it is prudent to assume that much of the increase is due to environmental exposure, which unmasks the underlying genetic susceptibility. Some of the proposed risk factors, such as dietary intakes of certain agents (e.g. milk proteins and caffeine) are common in the Finnish population [23-25].

The possibility that Type 1 diabetes is caused by a common viral infection has been previously suggested [26, 27] and intensively investigated during the past 20 years [28, 29]. Case reports and indirect evidence such as the seasonal variation in the manifestation of Type 1 diabetes exist that support this hypothesis. Otherwise the data are inconsistent $[30,31]$. Finland experienced a major epidemic of mumps during 1979-1980 and it is possible that the steep increase in the incidence of Type 1 diabetes in children during the subsequent years could to some extent be associated with it [32]. Since 1982 measles-mumps-rubella immunization has been implemented in Finland nationwide.

The familial aggregation of a disease is a good indicator of the relative importance of genetic factors in the disease risk. Type 1 diabetes in any first degree relative of the newly-diagnosed diabetic probands was found in $11.2 \%$ of the families and parental Type 1 diabetes in $8.2 \%$ of the families. These proportions are similar to those found in the nationwide Swedish Childhood Diabetes Study [33]. Although family history is the strongest known determi- 
nant of the disease the predictive power of family history of Type 1 diabetes in first degree relatives is, however, not very high. The majority of the cases are 'sporadic', with no history of Type 1 diabetes among first degree relatives. The prevalence of Type 1 diabetes in fathers of newly diagnosed Type 1 diabetic probands was about twice the prevalence in mothers in our study. This is in accord with previous findings from the USA [34] and Sweden [33]. The reasons for this phenomenon are not known. In general, diabetic women have less children than diabetic men.

Only six children with Type 1 diabetes were diagnosed before their first birthday. If the incidence in the other age groups were the same as under the age of 1 year, the overall incidence for the entire age range from 0 to 14 years should have been only about 3 per 100,000 . This illustrates that there is a potential for the primary prevention of Type 1 diabetes once the genetic susceptibility and environmental risk factors can be properly identified. Already in 1-4-year old children the incidence was over 30 per 100,000 in our present study. Obviously, something important happens very early in life or probably even in utero which increases the disease risk in Finnish children. According to our present data, the incidence further increased by about $25 \%$ from the 1-4-year old to 5-9-year old group. The previously reported pubertal peak in the incidence of Type 1 diabetes in Finland [16] was virtually missing.

Many chronic diseases show distinct and large geographic differences within Finland [35-39]. Earlier data suggested that the incidence of Type 1 diabetes might be somewhat higher in eastern Finland, and lower in northern Finland [1]. According to our present results Type 1 diabetes is equally distributed throughout the country. This may either mean that genetic differences in Finland are not very large or that there is a major environmental exposure which bas little geographic variation, or both. At the moment we cannot exclude either of these possibilities. The incidence of Type 1 diabetes in children in northern Sweden [40], where a large proportion of the population is of Finnish origin [41] is about $20 \%$ lower than that in Finland. The Estonians are the population linguistically and ethnically most closely related to the Finns. They live geographically close across the Baltic Sea, but in a culturally, behaviourally and socioeconomically different environment. In Estonia the incidence of childhood diabetes is about one third of that in Finland [42]. These observations can be taken as support for the importance of environmental factors in the development of Type 1 diabetes. We will evaluate the space-time clustering of the disease in further analyses in order to find out whether epidemic-like outbreaks occurred.

In order to be able to test hypotheses concerning the triggering mechanism of Type 1 diabetes in children who are genetically susceptible, similar epidemiologicallybased studies need to also be carried out in middle and low risk populations. It is possible that the factors which will explain why one child develops Type 1 diabetes, while another child does not, may also determine the differences in the risk of diabetes between populations. Populationbased genetic-epidemiological studies of Type 1 diabetes are likely to be the key not only for a better understanding of the development of Type 1 diabetes, but also for its prevention.

Acknowledgements. We thank the National Public Health Institute of Finland for invaluable financial support and the use of their facilities; all participating hospitals and the diabetes nurses who made the study possible; and all the family members who so willingly took part, and our staff in the Central Office and in various laboratories of the DiMe Study. The study was supported by grants from the $\mathrm{Na}$ tional Institutes of Health, USA (NIH grant DK - 37957), the Sigrid Juselius Foundation, the Association of Finnish Life Insurance Companies, the Nordisk Insulinfond, the Finnish Foundation for Diabetes Research, and the Foundation for the Memory of Dorothea Olivia, Karl Walter and Jarl Walter Perklén.

The Childhood Diabetes in Finland (DiMe) Study Group is composed of the following members:

Principal Investigators: H. K. Åkerblom, J. Tuomilehto

Coordinators: R. Lounamaa, L. Toivanen

Local Investigators: A. Fagerlund, M. Flittner, B. Gustafsson, A.Hakulinen, L.Herva, P.Hiltunen, T.Huhtamäki, N.-P.Huttunen, T.Huupponen, M.Hyttinen, C.Häggqvist, T.Joki, R.Jokisalo, S.Kallio, E.A.Kaprio, U.Kaski, M.Knip, M.-L.Käär, L.Laine, J.Lappalainen, J.Mäenpää, A.-L.Mäkelä, K.Niemi, A.Nïranen, A. Nuuja, P.Ojajärvi, T. Otonkoski, K.Pihlajamäki, S.Pöntynen, J.Ranjantie, J.Sankala, J.Schumacher, M. Sillanpää, C.-H. Stråhlmann, M.-R. Ståhlberg, T.Uotila, P. Varimo, G. Wetterstrand, M. Väre.

Special Investigators: A Aro (National Public Health Institute, Helsinki), H.Hurme ( $\AA$ bo Akademi, Pedagogic Faculty in Vaasa), H. Hyöty (Institute of Biomedical Sciences, University of Tampere), J. Ilonen (National Public Health Institute, Oulu), J. Karjalainen (Department of Pediatrics, University of Oulu), M. Knip (Department of Pediatrics, University of Oulu), R.LaPorte (Diabetes Research Center of Children's Hospital of Pittsburgh), P. Leinikki (National Public Health Institute, Helsinki), A. Miettinen (Department of Bacteriology and Immunology, University of Helsinki), L. Räsänen (Department of Nutrition, University of Helsinki), A.Reunanen (Social Insurance Institute, Helsinki), E. Savilahti (Children's Hospital, University of Helsinki), E.Tuomilehto-Wolf (National Public Health Institute, Helsinki), S. M. Virtanen (Department of Nutrition, University of Helsinki)

\section{References}

1. Reunanen A, Åkerblom HK, Käär ML (1982) Prevalence and ten-year (1970-1979) incidence of insulin-dependent diabetes in children and adolescents in Finland. Acta Paediatr Scand 71: 839-849

2. Christau B, Akerblom H, Joner G, Dahlqvist G, Ludvigsson J, Nerup J (1981) Incidence of childhood insulin-dependent diabetes mellitus in Denmark, Finland, Norway and Sweden. A workshop report. Acta Endocrinologica 98 [Suppl 245]: 68-80

3. LaPorte RE, Tajima N, Åkerblom HK et al. (1985) Geographic differences in the risk of insulin-dependent diabetes mellitus: the importance of registries. Diab Care 8 [Suppl 1]: 101-107

4. Diabetes Epidemiology Research International Group (1988) Geographic patterns of childhood insulin-dependent diabetes mellitus. Diabetes 37: 1113-1119

5. Rewers M, LaPorte RE, King H, Tuomilehto J (on behalf of the DERI Study Group) (1988) Trends in the prevalence and incidence of diabetes: insulin-dependent diabetes mellitus in childhood. World Health Stat Quart 41: 179-189

6. Ảkerblom HK, Reunanen A (1985) The epidemiology of insulindependent diabetes mellitus (IDDM) in Finland and in Northern Europe. Diab Care 8 [Suppl 1]: 10-16 
7. Reunanen A, ̊̊kerblom HK, Tuomilehto J (1988) High incidence of insulin-dependent diabetes mellitus (IDDM) in children in Finland. Arct Med Res 47 [Suppl 1]: 535-539

8. Tuomilehto J, Rewers M, Reunanen A et al. (1991) Increasing trend in Type 1 (insulin-dependent) diabetes mellitus in childhood in Finland. Analysis of age, calendar time and birth cohort effects during 1965 to 1984 . Diabetologia $34: 282-287$

9. Bertrams J, Baur MP (1984) Insulin-dependent diabetes mellitus. In: Albert ED, Baur MP, Mayr WR (eds) Histocompability Testing Springer, Berlin Heidelberg New York, pp 348-358

10. Diabetes Epidemiology Research International (1987) Preventing insulin dependent diabetes mellitus: the environmental challenge. Br Med J 295: 479-481

11. Rayfield EJ, Ishimura K (1987) Environmental factors and insulin dependent diabetes mellitus. Diab Metabol Rev 3: 925-957

12. Eisenbarth GS (1986) Type 1 diabetes mellitus. A chronic autoimmune disease. N Engl J Med 314: 1360-1368

13. Bottazzo GF, Bonifacio E, Wagner R, Al-Sakkaf L, Dean BM, Mirakian R (1990) On the pathogenesis of Type 1 (insulin-dependent) diabetes mellitus: facts, areas still under development and new perspectives. Klin Wochenschr 68 [Suppl 21]: 26-37

14. Tuomilehto J, Wolf E (1987) Primary prevention of diabetes mellitus. Diab Care 10: 238-248

15. National Diabetes Data Group (1979) classification and diagnosis of diabetes mellitus and other categories of glucose intolerance. Diabetes 28: 1039-1057

16. Åkerblom HK, Reunanen A, Käär M-L (1980) The incidence of insulin-dependent diabetes mellitus in 0-14-year old children in Finland in 1970-78. Nordic Council Arct Med Res 26: 60-66

17. Rubinstein P, Sucio-Foca N, Nicholson JF (1977) Genetics of juvenile diabetes mellitus. N Engl I Med 297: 1036-1040

18. Spielman RS, Baker L, Zmijewski CM (1980) Gene dosage and susceptibility to insulin-dependent diabetes. Ann Hum Genet 43: $135-150$

19. Thomson G (1980) A two locus model for juvenile diabetes. Ann Hum Genet 43: 383-398

20. Hodge SE, Rotter JI, Lange KL (1980) A three-allele model for heterogeneity of juvenile onset insulin-dependent diabetes. Ann Hum Genet 43: 399-412

21. Tuomilehto-Wolf E, Tuomilehto J, Lounamaa R, Cepaitis Z and the DiMe study group (1989) New susceptibility haplotype for Type 1 diabetes in Finland. Lancet II: 299-302

22. Somersalo O (1955) Studies of childhood diabetes. I. Incidence in Finland. Ann Paediatr Fenn 1:239-249

23. Elliott RB, Martin JM (1984) Dietary protein: a trigger of insulin-dependent diabetes in the BB rat? Diabetologia 26: 297-299

24. Scott FW (1990) Cow milk and insulin-dependent diabetes mellitus: is there a relationship? Am J Clin Nutr 51:489-491

25. Tuomilehto J, Tuomilehto-Wolf E, Virtala E, LaPorte RE (1990) Coffee consumption as trigger for insulin-dependent diabetes mellitus in childhood. Br Med J 300: 642-643

26. Hay DR (1949) The relation of maternal rubella to congenital deafness and other abnormalities in New Zealand. NZ Med J 48; 604-608

27. Gamble DR, Kinsley ML, Fitzgerald MG, Bolton R, Taylor KW (1969) Viral antibodies in diabetes mellitus. Br Med J 3: 627-630

28. Krolewski AS, Warram JH, Rand LI, Kahn CR (1987) Epidemiologic approach to the etiology of Type 1 diabetes mellitus and its complications. NEngl J Med 317:1390-1398
29. Yoon J-W (1990) Viral pathogenesis of insulin-dependent diabetes mellitus. In: Ginsberg-Fellner F, McEvoy RC (eds) Autoimmunity and the pathogenesis of diabetes. Springer, New York, pp 206-255

30. Yoon JW, Ray UR (1985) Perspectives on the role of viruses in insulin-dependent diabetes. Diab Care 8 [Suppl 1]: 39-44

31. Barrett-Connor $\mathrm{E}$ (1985) Is insulin-dependent diabetes mellitus caused by coxsackievirus B infection? A review of the epidemiologic evidence. Rev Inf Dis 7:207-215

32. Hyöty H, Leinikki P, Reunanen A et al. (1988) Mumps infections in the etiology of Type 1 (insulin-dependent) diabetes. Diabetes Res 9: 111-116

33. Dahlqvist G, Blom L, Tuvemo T, Nyström L, Sandström A, Wall S (1989) The Swedish childhood diabetes study - Results from a nine year case register and a one year case-referent study indicating that Type 1 (insulin-dependent) diabetes mellitus is associated with both Type 2 (non-insulin-dependent) diabetes mellitus and autoimmune disorders. Diabetologia 32:2-6

34. Warram JH, Krolewski AS, Gottlieb MI, Kalm CR (1984) Differences in risk of insulin-dependent diabetes in offspring of diabetic mothers and diabetic fathers. N Engl J Med 311:149-152

35. Pyörälä K, Salonen JT, Valkonen T (1985) Trends in coronary heart disease mortality and morbidity and related factors in Finland. Cardiology 72:35-51

36. Hakulinen T, Andersen A, Mahler B, Pukkala E, Schon G, Tulinius $H$ (1986) Trends in cancer incidence in the Nordic countries. A collaborative study of the five Nordic Cancer Registries. Acta Pathol Microbiol Immunol Scand 288: 1-151

37. Kinnunen E (1984) Multiple sclerosis in Finland: evidence of increasing frequency and uneven geographic distribution. Neurology $34: 457-461$

38. Haahtela T, Heiskala M, Suoniemi I (1980) Allergic disorders and immediate skin test reactivity in Finnish adolescents. Allergy 35: 433-441

39. Hausen H, Milen A, Heinonen OP, Paunio I (1982) Caries in primary dentition and social class in high and low fluoride areas. Comm Dent Oral Epidemiol 10: 33-36

40. Hägglöf B, Holmgren G, Wall S (1982) Incidence of insulin-dependent diabetes mellitus among children in a North-Swedish population 1938-1977. Hum Hered 32: 408-417

41. Beckman G, Beckman L, Cedergren B, Nordenson I (1975) Population studies in northern Sweden. VII. Serum transferrin variants as markers of Finnish admixture. Hereditas 81: 63-68

42. Kalits I, Podar T (1990) Incidence and prevalence of Type 1 (insulin-dependent) diabetes in Estonia in 1988. Diabetologia 33: 346-349

Received: 28 March 1991

and in revised form: 17 September 1991

Dr. J. Tuomilehto

National Public Health Institute

Department of Epidemiology

Elimäenkatu $25 \mathrm{~A}$

SF-00510 Helsinki

Finland 